\title{
Research on Social Responsibilities of Enterprise from the Perspective of Economic Law
}

\author{
Xiaojie Liu \\ Tianjin University, Tianjin, 300072, China
}

Keywords: Social responsibilities, Economic law, Legal regulation

\begin{abstract}
In modern society, as an active market subject, enterprises should take responsibilities for their employees, consumers and environment besides their own development responsibilities. Therefore, China's economic laws have laid out relevant provisions to regulate corporation's social responsibilities from the legislative level. This paper analyses the system improvement measures of social responsibilities of enterprise from the perspective of economic law to provide some references for the relative researchers.
\end{abstract}

\section{Introduction}

Our country is vigorously promoting a harmonious society and a stable and stable social environment, but the social contradictions in our country are becoming more and more serious [1]. The occurrence of this situation requires us to continuously strengthen the establishment of the system. The social principle of economic law is to better promote the stability of social order, better promote the optimization of economic structure, and make the market order more harmonious. It ensures that the role of economic law can run through the theoretical system and achieve positioning and value. Social responsibility refers to no matter what type of business should be based on the principle of sustainable development to better realize their diversification and management tasks, to ensure their own economic interests to achieve the basic interests of the reasonable number of employees, all kinds of product configuration, regional personnel can be effectively protected. In fact, the range of social responsibility of various types of enterprises in China is becoming wider and wider. Although there are great differences between traditional and Chinese forms of social responsibility, we can still agree on the control of social responsibility. In addition, the international corporate social responsibility measures covered gradually widely, most countries and regions have successively according to their actual situations of law revision, corporate social responsibility also clearly stated, the social responsibility system gradually toward the direction of development and different areas, gradually formed the main decision-making indispensable guidance. On this basis, social responsibility can be properly regulated in economic law, and can also be expanded to the content of social responsibility [2].

\section{Main Contents of Social Responsibilities of Enterprise}

\subsection{Responsibility to Protect the Rights and Interests of the Workers}

The enterprise is the basic body of the economic life, and the employee is the support force of the enterprise development, and it is one of the most important stakeholders of the enterprise. Therefore, the enterprise should first bear the responsibility of ensuring and promoting the rights and interests of the workers. China's labor law, occupation disease prevention law and the rights and obligations of employees is closely related to the law in the specified enterprise undertakes to ensure that the workers receive reasonable labor compensation responsibility and occupation disease prevention and control responsibilities for the employee, but these enterprises cannot cover all the responsibility of employees, employees as the mainstay of production and operation of enterprises and devote 
themselves to the development of enterprises, and enterprises also bear the training staff to continuously improve work ability and comprehensive quality of social responsibility, such as providing related technical training responsibilities for employees, employees contribute to achieve all aspects of literacy. To sum up, the responsibilities of employees include three aspects: one is to protect employees' legal rights; the two is to protect employees' rights to participate in business management; the three is to provide personal development training platform for employees [3].

\subsection{Responsibility to Protect the Rights and Interests of the Consumers}

The foundation of ensuring the profit of the enterprise is to guarantee the customer's responsibility to obtain the fair and fair transaction and to obtain the trust of the consumer of the product or service. However, under the market economy environment, some business operators and managers violate professional ethics and relevant laws and regulations to pursue immediate and short-term economic benefits, but also undermine other market main market image, more loss of consumers for some products or services market integrity, such as triggered by the Sanlu milk powder incident, people on the quality of the whole national security incidents in the milk industry questioned, this kind of event be too numerous to enumerate. These bad behavior, not only caused the great loss of welfare to the consumer, but also made the enterprise unsustainable because of losing faith in the consumer and was in danger. Therefore, it is one of the social responsibilities that enterprises must bear to maintain the proper order of the market and protect the legitimate rights and interests of the consumers. China's consumer protection law, product quality law and other laws have made specific provisions, enterprises should strengthen self-discipline, strengthen the occupation morals construction, consciously abide by the relevant laws and regulations, undertake the courtesy and honesty, legitimate business, to ensure that the products and services to protect the consumers get genuine goods at a fair price, the integrity of the social responsibility even bargain [4].

\subsection{Responsibility to Protect Environment}

An enterprise is responsible for all the real and potential beneficiaries of the environment and resources. That is to give them the right to use natural resources. He must achieve it through the protection and rational use of the environment and resources. Because he is not only related to the vital interests of contemporary mankind, but also related to the survival and development of future generations. It is the premise and key to achieve sustainable development of human society. Enterprises are responsible for the protection and rational utilization of environment and resources. This is the embodiment of enterprises' responsibility for all mankind and future generations. Therefore, the responsibility of enterprises is a typical corporate social responsibility. The responsibility of environmental protection is natural in the operation of the enterprise. If the operation process of an enterprise pollutes the environment and harms health, even if the company has done many good deeds, how much money has been donated, they will fail in fulfilling their social responsibilities. From the current situation, major rivers have been polluted, the city's air quality is very poor, the natural environment has been ravaged, which produced China future consequences are far more serious than no charity. The cause of this phenomenon is that enterprises have not been responsible for the basic environmental protection for the development of the economy.

\section{Legalization Significance of Social Responsibilities of Enterprise}

The legalization of corporate social responsibility can not only avoid the negative effects of state direct intervention, but also is the objective need for enterprises to reduce transaction costs and maximize profits. External diseconomy refers to the adverse effects of a certain activity and the social environment, while the perpetrator does not pay the corresponding compensation fee for this. The external economy means that a certain activity has a good influence on the natural and social environment, but the perpetrator has not benefited. The external uneconomic behavior of the enterprise shows that the enterprise should bear social responsibility and compensate for the loss of the society. Based on the nature of the rational economy, the enterprise will bring negative 
externalities to its stakeholders. But not everyone thinks that the enterprise has negative externalities. On the contrary, the enterprise produces positive externalities. The enterprise does not attempt to increase public welfare, nor does it know how much public welfare he has increased. When he uses his capital to make the maximum value of its output, he is pursuing only personal interests. In doing so, there is an invisible hand that leads him to a goal, which is not what he is pursuing. When the enterprise is pursuing his own interests, it often promotes the interests of the society, that is, the positive externality. That is, in the free market economy, the self-interest of the enterprise can automatically lead to the maximization of social welfare. In fact, the individual interests of the enterprise are not necessarily consistent with the social interests. In modern economics, because of the existence of external factors, the market cannot achieve full risk transfer. And most importantly, it also has a lot of negative externalities, such as environmental pollution violated the public's environmental right; the lack of safety management measures to the workplace, violation of the right to health workers, work safety production; the sale of fake and shoddy products infringes consumer rights, abuse of economic advantages violates the rights of the same enterprise. The above economic activities must be regulated by law.

\section{System Improvement Paths of Social Responsibilities of Enterprise from the Perspective of Economic Law}

\subsection{System Improvement of Rights and Interests Protection of the Workers}

To achieve our corporate social responsibility, enterprises should actively transform the governance mode of enterprises, and gradually strengthen the voice of employees in decision-making. Only in this way can the will of the employees be truly reflected in the decision of the enterprise. In the perspective of economic law, corporate social responsibility not only need to consider the legal responsibility of enterprises, enterprises should also be moral responsibility in the production operation in consideration of responsibility, through the strengthening of corporate social responsibility system construction, encourage enterprises to take the initiative to assume responsibility for social morality. These laws and regulations have played a positive role in protecting the rights and interests of the employees in our country. But because of its own low operating and too principled regulation. At present, China is in the period of the contradiction between labor and capital, and the contradiction between labor and capital is becoming more and more intense. These contradictions are mainly for enterprises in the deduction of wages, unpaid social insurance premiums, terminate the contract compensation, accident compensation, enterprise restructuring or equity disputes, most of which is due to the passive or refuses to perform the legal obligations of the service should bear caused. Therefore, in the increasingly prominent contradiction between labor and capital in Chinese enterprises, it is emphasized that the fulfilment of corporate social responsibilities or obligations has a more direct practical significance for the stability and harmony of labor relations in enterprises.

\subsection{System Improvement of Rights and Interests Protection of the Consumers}

At present, the protection of the rights and interests of consumers has attracted much attention, and the protection of the legitimate rights and interests of consumers undoubtedly occupies an important position in the economic law. In the regulation of economic law, enterprises should try to make the health and safety of consumers from harm, promote and protect the economic interests of consumers, so that consumers get enough information so that they can make specific choices according to their own desires and needs, and must provide effective and timely compensation to consumers. The consumer protection law involves interest issues, which should be fully concerned by the society. The object of economic law adjustment is the economic management relationship based on the social public nature. The economic law is accompanied by the development of market economy. Its existence is based on the social interest, emphasizing the scientific adjustment of social and economic operation from the overall interest. In other words, the essential attributes of economic law are 
interests and resources distribution, social standard law and economic development, which emphasize the social standard. In order to encourage enterprises to take the initiative to take social responsibility, should be carried out from two aspects of mandatory and non-mandatory, the enthusiasm of the excessive rigid system of corporate social responsibility may cause some negative impact, will also affect the legal system to achieve efficiency, therefore, the system construction can be carried out social responsibility from the following aspects: first of all that should adhere to the appropriate principles of social responsibility system flexible, both to ensure the social behavior of enterprises must promote the economic interest of the whole society, but also the requirement of social behavior of enterprises should be conducive to the development of their own enterprises, secondly, to take flexible way of corporate social responsibility on the way should, according to the enterprise the actual situation and business direction, take a flexible way to fulfill their social responsibilities.

\subsection{System Improvement of Environment Protection}

We should raise funds for compensation for victims of environmental pollution through financial investment, tax collection and social donation, to provide relief for victims of environmental pollution. It is a powerful supplement to environmental pollution, and its essence is the socialization of responsibility sharing. The compensation fund has the characteristics of basic, positive and final guarantee. A way of transferring funds to traditional society is a way to transfer to society. It forms a relief to the polluters' out of control and realizes the transformation from individual responsibility to social standard, which promotes social equity. In view of the status quo of the environmental responsibility of our country, we should establish a legal supervision, social supervision of the multi supervision mechanism of multiple governance is actively supervise in fully mobilize the body of society, government and industry organizations, consumers, social media to participate in the operation, the construction of benign interactive mechanism of multiple supervision. In the form of effective government supervision, scientific assessment, social intermediary cooperation. Government regulation is mandatory, organized and institutionalized, but the cost is also high. Enterprises only require the lowest standard stipulated by law. Although social supervision is lack of compulsion, it has the advantages of strong forewarning, wide coverage and high demand for enterprises. The establishment of public interest litigation cost system. To protect the public's environmental rights, we should change the standard of collection of the cost of litigation and establish the cost system of public interest litigation. If we win the lawsuit in public interest litigation, we shall decide that the defendant is responsible for all the costs involved and improve the enthusiasm of citizen's environmental public interest litigation. Improve the incentive mechanism. We can give a certain reward to the plaintiff from the indemnity of the defendant or the environmental fund set up by the state, the local government and the organization by the law.

\section{Conclusions}

The implementation of corporate social responsibility is the common trend of the global economy and the development of enterprises. With the gradual integration and integration of China's economy and the world economy, our economic development must meet the common requirements of the development of the world economy. Only in this way can the harmonious and orderly development of economy and society be realized.

\section{References}

[1] Qian Shuixiang, Ge Xiaolin. On the Path of Economic Responsibility Audit Servicing State Governance from the Perspective of Ruling the Country by Law [J]. Zhejiang Social Sciences, 2015(2): 137-141+160.

[2] Yu Yao. With the economic analysis of law the social responsibility of the enterprise ecological environment [J]. Journal of Jilin Institute of Chemical Technology [J]. 2014, 31(4): 96-98. 
[3] Wang Yuben. Social Responsibility Theory of Economic Law: The Ideological Basis of Social Management [J]. Law Science Magazine, 2012(11): 73-77.

[4] Wu Ruirong. A Study on the Social Responsibilities of Corporation from the Perspective of Economic Law [J]. Journal of North University of China (Social Science Edition), 2016, 32(5): 24-27. 